\title{
STUDI DESKRIPSI TENTANG TINGKAT KESULITAN BELAJAR SISWA KELAS VIII DI SMP NEGERI 50 BATAM
}

\author{
Mahrani Dita Putri ${ }^{1}$, Junierissa Marpaung ${ }^{2}$ \\ Program Studi Bimbingan Konseling Universitas Riau Kepulauan Batam \\ junierissa_marpaung@yahoo.com
}

\begin{abstract}
ABSTRAK
Belajar adalah suatu proses usaha yang dilakukan untuk memperoleh suatu perubahan tingkah laku, perwujudan perubahan tingkah laku hasil belajar seperti adanya peningkatan kemampuan siswa sesuai dengan tujuan yang telah ditetapkan. Realitanya masih ada siswa yang mengalami hambatan dalam proses belajar. Berdasarkan survei awal, rata-rata siswa memiliki nilai dibawah KKM yaitu 75 dan terdapat siswa yang mengalami hambatan dalam proses belajar. Tujuan penelitian ini adalah untuk mengetahui tingkat kesulitan belajar siswa. Penelitian ini dilaksanakan menggunakan metode kuantitatif dengan jenis penelitian deskriptif. Adapun yang menjadi populasi dalam penelitian adalah siswa kelas VIII dengan jumlah siswa 214 siswa. Teknik pengambilan sampel yang digunakan oleh peneliti adalah proportional random sampling. Dengan teknik tersebut, maka jumlah sampel yang diambil peneliti adalah 140 orang siswa. Alat pengumpulan data yang digunakan adalah angket kesulitan belajar. Analisis data menggunakan tingkat persentase. Berdasarkan hasil analisis data dan pembahasan dari hasil penelitian, maka dapat disimpulkan bahwa: Tingkat kesulitan belajar siswa kelas VIII di SMP Negeri 50 Batam dengan hasil 43,60\% dari 140 siswa termasuk dalam kategori sedang. Adapun klasifikasi kesulitan belajar tertinggi yang dialami oleh siswa kelas VIII di SMP Negeri 50 Batam adalah terdapat pada klasifikasi kesulitan belajar memory disorder dengan persentase $42 \%$. Sedangkan klasifikasi kesulitan belajar terendah sebesar $43 \%$ dalam klasifikasi menghitung. Disarankan siswa untuk membuat jadwal belajar, membaca sebelum memulai pelajaran, mengerjakan setiap tugas yang diberikan guru, dan meningkatkan semangat belajar.
\end{abstract}

Kata kunci : tingkat kesulitan belajar siswa

\begin{abstract}
Learning is a process attempts to obtain a change in behavior, the embodiment of the learning outcomes of behavioral changes such as an increase in the ability of students in accordance with its intended purpose. In reality, there are still students who experience barriers to learning. Based on the initial survey, the average student has a value below KKM is 75 and there are students who experience barriers to learning. The purpose of this study was to determine the level of students' learning difficulties. This study was conducted using quantitative methods with descriptive research. As for the population in the study were students of class VIII student numbers 214 students. The sampling technique used by the researchers is proportional random sampling. With this technique, the number of samples taken by researchers is 140 students. Data collection tool is questionnaire learning difficulties. Analysis of data using a
\end{abstract}


percentage rate. Based on the analysis and discussion of the research results, it can be concluded that: The difficulty level class VIII student at SMP Negeri 50 Batam with the result $43.60 \%$ of 140 students included in the medium category. The highest classification learning difficulties experienced by students of class VIII SMP Negeri 50 Batam is located on the classification of learning difficulties memory disorder with the percentage of $42 \%$. While the classification of learning difficulties low of $43 \%$ in calculating classification. Advised the students to make a study schedule, read before starting the lesson, do any assignment of teachers, and promote the spirit of learning.

Keywords: learning difficulties level of student

\section{PENDAHULUAN}

Undang-Undang Nomor 20 Tahun 2003 tentang sistem pendidikan nasional menyatakan bahwa "Pendidikan Nasional bertujuan untuk berkembangnya potensi siswa agar menjadi manusia yang beriman bertakwa kepada Tuhan Yang Maha Esa, berakhlak mulia, sehat, berilmu, cakap, kreatif, mandiri dan menjadi warga negara yang demokratis serta bertanggung jawab". Tujuan pendidikan tersebut dapat dicapai melalui proses belajar.

Thursan Hakim (2000) mengatakan bahwa belajar adalah suatu proses perubahan dalam kepribadian manusia dan perubahan tersebut ditampakkan dalam bentuk peningkatan kualitas dan kuantintas tingkah laku seperti peningkatan kecakapan, pengetahuan, sikap, kebiasaan, pemahaman, keterampilan, daya pikir dan lain-lain kemampuan. Selanjutnya, Slameto (2003) mengatakan bahwa belajar adalah suatu proses usaha yang dilakukan seseorang untuk memperoleh suatu perubahan tingkah laku yang baru secara keseluruhan, sebagai hasil pengalamannya sendiri dalam interaksi dengan lingkungannya.

Pendapat para ahli tersebut, dapat disimpulkan bahwa belajar merupakan suatu proses atau usaha yang dilakukan seseorang untuk memperoleh peningkatan kualitas dan kuantitas, sebagai hasil pengalamannya sendiri dalam interaksi dengan lingkungannya. Seseorang dapat dikatakan belajar karena ada indikasi melakukan proses tersebut secara sadar dan menghasikan perubahan tingkah laku siswa yang diperoleh berdasarkan interaksi dengan lingkungan. Perwujudan perubahan tingkah laku hasil belajar adalah ada peningkatan kemampuan siswa sesuai dengan tujuan yang telah ditetapkan. 
Dalam upaya mencapai tujuan belajar yang diinginkan, sering kali ditemukan permasalahan dalam proses pembelajaran seperti rendahnya hasil belajar yang dicapai oleh siswa dan kesulitan yang dialami siswa dalam mengikuti serta memahami pelajaran. Ahmadi dan Supriyono (2013) mengatakan aktivitas belajar bagi setiap individu tidak selamanya berlangsung secara wajar seperti, kadang-kadang lancar, kadang-kadang tidak, kadang-kadang dapat cepat menangkap apa yang dipelajari, kadang-kadang terasa amat sulit untuk mengadakan konsentrasi.

Berkaitan dengan hal tersebut, Mulyono Abdurrahman (2009) mengatakan bahwa kesulitan belajar adalah suatu kondisi yang menimbulkan hambatan dalam proses belajar seseorang. Hambatan itu menyebabkan orang tersebut mengalami kegagalan atau setidaktidaknya kurang berhasil dalam mencapai tujuan belajar. Berdasarkan dari pendapat-pendapat tersebut dapat disimpulkan bahwa kesulitan belajar merupakan kondisi yang menimbulkan hambatan dalam proses belajar.

Hasil wawancara peneliti dengan 10 orang siswa dan guru mata pelajaran serta pengamatan awal yang peneliti lakukan pada saat PLK-S dari tanggal 03 Agustus 2015 sampai 5 Desember 2015 di SMP Negeri 50 Batam, diperoleh informasi bahwa, 1) rata-rata siswa memiliki nilai di bawah KKM yaitu 75, 2) Siswa sering lupa tugas yang diberikan guru, 3) Siswa yang sulit berkonsentrasi pada saat belajar sehingga menimbulkan keributan di kelas, 4) Siswa sulit melakukan fungsi matematika seperti menambah, mengurang, membagi atau mengkali. Hasil wawancara tersebut dapat disimpulkan bahwa siswa SMP Negeri 50 Batam terindikasi mengalami kesulitan belajar.

Berangkat dari permasalahan yang peneliti temui di lapangan, maka peneliti tertarik untuk mengkaji lebih dalam mengenai kesulitan belajar yang dialami siswa melalui penelitian dengan judul Studi Deskripsi Tentang Tingkat Kesulitan Belajar Siswa Kelas VIII SMP Negeri 50 Batam.

\section{KAJIAN TEORI}

Kesulitan belajar adalah suatu kondisi yang dialami oleh peserta didik dalam menjalani proses belajar dimana siswa tidak dapat belajar sebagaimana mestinya yang ditandai dengan adanya hambatan-hambatan dalam memperoleh hasil belajar sehingga prestasi yang dicapai tidak sesuai dengan kriteria standar yang telah ditetapkan. 
Cece Widjaya (1996) mengemukakan bahwa ciri-ciri atau gejala siswa lamban (mengalami kesulitan belajar) dapat ditinjau dari beberapa sisi, antara lain dari sisi proses belajar yang dilakukannya. Ciri-ciri siswa yang mengalami kesulitan belajar ditinjau dari sisi ini adalah sebagai berikut:

a. Lamban mengamati dan mereaksi peristiwa yang terjadi dilingkungannya

b. Kurang berminat untuk melakukan penyelidikan terhadap hal-hal yang baru dilingkungannya

c. Tidak banyak mengajukan pertanyaan, apalagi pertanyaan-pertanyan yang mengandung unsur problematik yang menuntut pemecahan masalah, dan sangat sulit mengikuti pelajaran yang disajikan

d. Kurang memperlihatkan perhatian terhadap apa dan bagaimana tugas dapat diselesaikan dengan baik

e. Banyak menggunakan ingatan (hafalan) daripada logika (reasoning)

f. Tidak mampu menggunakan cara-cara tertentu dalam mempelajari ilmu pengetahuan

g. Kurang lancar berbicara, tidak jelas, dan gagap

h. Sangat bergantung kepada gurunya dan orang tuanya, terutama untuk membuktikan kebenaran pengetahuan yang sedang dipelajarinya

i. Sulit memahami konsep-konsep abstrak

j. Sulit memindahkan kecakapan tertentu yang telah dikuasainya ke dalam kecakapan lainnya (transfer) sekalipun dalam mata pelajaran yang sama

k. Lebih sering berbuat salah

1. Mengalami kesulitan membuat generalisasi pengetahuan secara terurai, bahkan tidak mampu menarik kesimpulan

m. Memiliki daya ingat yang lemah atau mudah lupa

n. Mengalami kesulitan dalam menuliskan pengetahuannya, sekalipun dengan menggunakan kata dan kalimat sederhana, dan

o. Lambat mengerjakan tugas-tugas atau latihan-latihan yang diberikan, baik di sekolah maupun di rumah 
Menurut Kirk \& Gallagher (1986) kesulitan belajar dapat dikelompokkan menjadi dua kelompok besar yaitu:

\section{a. Developmental Learning Disabilities}

1) Perhatian (attention disorder) Anak dengan attention disorder akan berespon pada berbagai stimulus yang banyak. Anak ini selalu bergerak, sering teralih perhatiannya, tidak dapat mempertahankan perhatian yang cukup lama untuk belajar dan tidak dapat mengarahkan perhatian secara utuh pada sesuatu hal.

\section{2) Memory Disorder}

Memory disorder adalah ketidakmampuan untuk mengingat apa ynag telah dilihat atau didengar ataupun dialami. Anak dengan masalah memori visual dapat memiliki kesulitan dalam me-recall kata-kata yang ditampilkan secara visual. Hal serupa juga dialami oleh anak dngan masalah pada ingatan auditorinya yang mempengaruhi perkembangan bahasa lisannya.

3) Gangguan persepsi visual dan motorik

Anak-anak dengan gangguan persepsi visual tidak dapat memahami rambu-rambu lalu lintas, tanda panah, kata-kata yang tertulis, dan simbol visual yang lain. Mereka tidak dapat menangkap arti dari sebuah gambar atau angka atau memiliki pemahaman akan dirinya.

4) Thinking Disorder

Thinking disorder adalah kesulitan dalam operasi kognitif pada pemecahan masalah pembentukan konsep dan asosiasi. Thinking disorder berhubungan dengan gangguan dalam berbahasa verbal.

5) Language Disorder

Merupakan kesulitan belajar yang paling umum dialami pada anak pra-sekolah. Biasanya anak-anak ini tidak berbicara atau berespon dengan benar terhadap instruksi atau pernyataan verbal.

\section{b. Academic Learning Disabilities}

Adalah kondisi yang menghambat proses belajar yaitu dalam membaca, mengeja, menulis, atau menghitung. Ketidakmampuan ini muncul pada saat anak menampilkan kinerja di bawah potensi akademik mereka. 


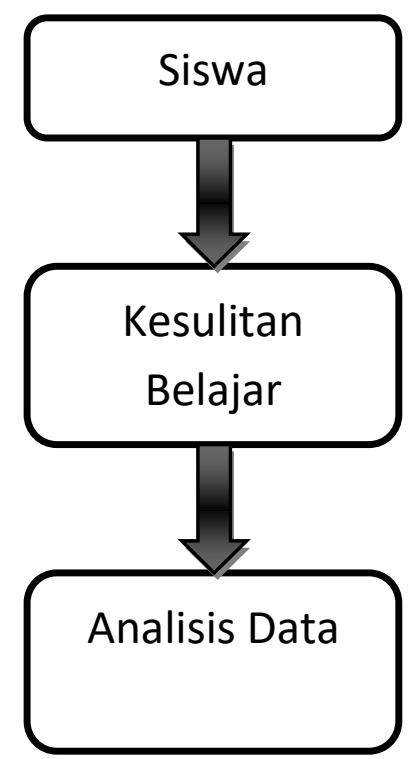

Gambar 1. Kerangka Pemikiran

\section{METODE PENELITIAN}

Jenis penelitian ini adalah penelitian kuantitatif deskriptif dengan pendekatan kuantitatif. Berdasarkan tabel Krejcie (Sugiyono,2013) dengan N=214 diperoleh sampel sebanyak 140 siswa. Selanjutnya pengambilan sampel penelitian dilakukan dengan mempertimbangkan aspek jumlah siswa pada masing-masing kelas, sehingga dilakukan pengambilan sampel dengan menggunakan pertimbangan teknik Proportional Random Sampling. Teknik pengumpulan data yang digunakan dalam penelitian ini adalah dengan metode skala mengenai kesulitan beajar siswa pada siswa. Analisis data yang dilakukan adalah untuk mendeskripsikan tingkat kesulitan belajar siswa di sekolah dengan menggunakan rumus persentase dan kategorisasi.

\section{HASIL PENELITIAN}

\section{Kesulitan belajar siswa dilihat dari tingkat kategorisasi kesulitan belajar siswa}

Berdasarkan perhitungan pada tabel di atas, maka diketahui bahwa dari 140 orang siswa SMP Negeri 50 Batam, terdapat 3,5\% atau 5 orang siswa mengalami kesulitan belajar yang termasuk dalam kategori sangat rendah. Sedangkan dalam kategori rendah sebanyak 20,7\% atau 29 orang siswa yang mengalami kesulitan belajar. Kategori sedang sebanyak 43,6\% atau 61 orang siswa. Kategori tinggi sebanyak 26,5\% atau 37 orang siswa yang mengalami 
kesulitan belajar. Sedangkan 5,7\% atau 8 orang siswa mengalami kesulitan belajar dalam kategori sangat tinggi. Dari data di atas, dapat disimpulkan bahwa tingkat kesulitan belajar siswa kelas VIII di SMP Negeri 50 termasuk dalam kategorisasi sedang yaitu sebanyak $40,7 \%$ atau 57 orang siswa .

Tabel 1. Persentase Tingkat Kategorisasi Kesulitan Belajar Siswa

\begin{tabular}{|l|l|}
\hline \multicolumn{1}{|c|}{ Kategorisasi } & \multicolumn{1}{c|}{ Persentase } \\
\hline Sangat Rendah & $\frac{8}{140} \times 100 \%=\mathbf{5 , 7 \%}$ \\
\hline Rendah & $\frac{37}{140} \times 100 \%=\mathbf{2 6 , 5 \%}$ \\
\hline Sedang & $\frac{61}{140} \times 100 \%=\mathbf{4 3 , 6 \%}$ \\
\hline Tinggi & $\frac{29}{140} \times 100 \%=\mathbf{2 0 , 7 \%}$ \\
\hline Sangat Tinggi & $\frac{5}{140} \times 100 \%=\mathbf{3 , 5 \%}$ \\
\hline
\end{tabular}

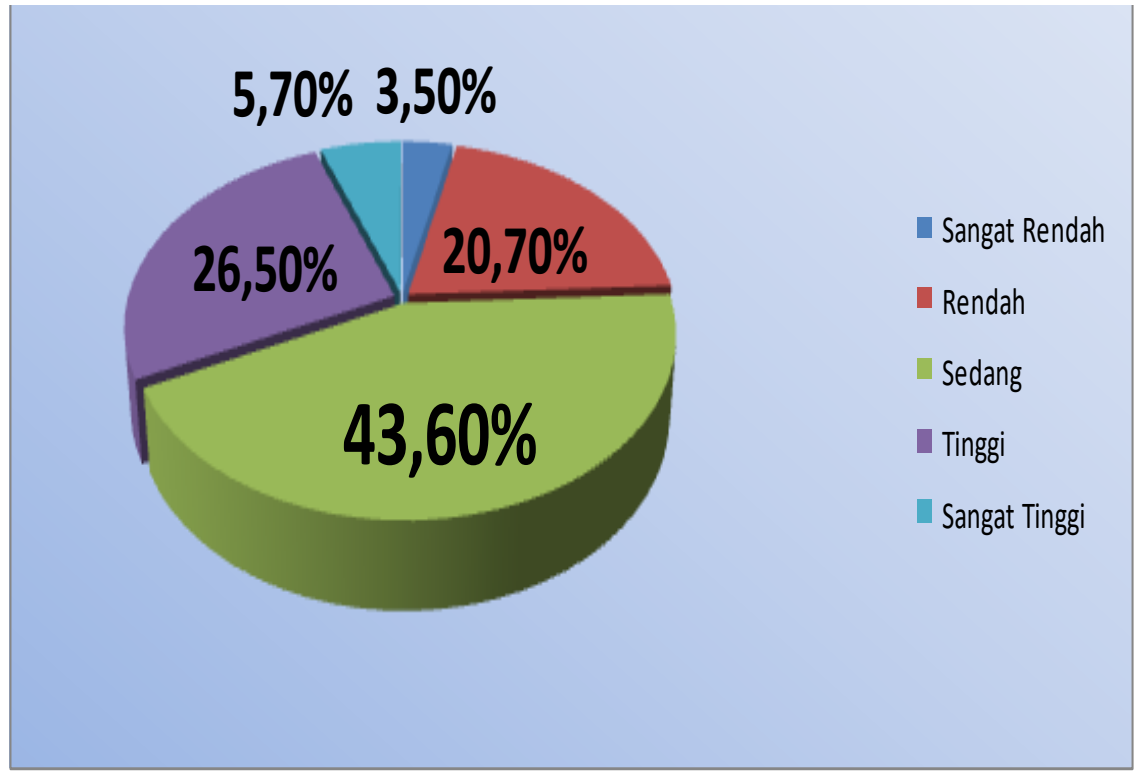

Gambar 2. Tingkat Kategorisasi Kesulitan Belajar Siswa 


\section{Kesulitan Belajar Siswa dilihat dari Klasifikasi Kesulitan Belajar}

Tabel 2. Persentase Klasifikasi Kesulitan Belajar Siswa

\begin{tabular}{|l|c|c|c|c|c|c|c|c|c|c|}
\hline \multirow{2}{*}{\multicolumn{1}{c|}{ Indikator }} & \multicolumn{2}{|c|}{ ST } & \multicolumn{2}{c|}{ T } & \multicolumn{2}{c|}{ S } & \multicolumn{2}{c|}{ R } & \multicolumn{2}{c|}{ SR } \\
\cline { 2 - 12 } & F & \% & F & $\mathbf{\%}$ & F & \% & F & \% & F & \% \\
\hline Perhatian & 37 & 26 & 59 & 42 & 31 & 22 & 10 & 7 & 2 & 1 \\
\hline Memory Disorder & 4 & 3 & 24 & 17 & 40 & 29 & 51 & 36 & 19 & 14 \\
\hline Gangguan Persepsi Visual & 18 & 13 & 29 & 21 & 42 & 30 & 35 & 25 & 15 & 11 \\
\hline Thingking Disorder & 7 & 5 & 43 & 31 & 65 & 46 & 17 & 12 & 7 & 5 \\
\hline Membaca & 0 & 0 & 21 & 15 & 30 & 21 & 51 & 36 & 36 & 26 \\
\hline Menulis & 3 & 2 & 13 & 9 & 23 & 16 & 38 & 27 & 60 & 43 \\
\hline Menghitung & 11 & 8 & 37 & 26 & 47 & 34 & 38 & 27 & 6 & 4 \\
\hline
\end{tabular}

Keterangan:

ST : Sangat Tinggi; T : Tinggi; S : Sedang; R : Rendah; SR : Sangat Rendah

Berdasarkan hasil perhitungan pada tabel di atas, maka diketahui bahwa dari 140 orang siswa SMP Negeri 50 Batam, terdapat 36\% siswa mengalami kesulitan belajar yang termasuk dalam klasifikasi memory disorder dalam kategori sangat tinggi, 42\% siswa mengalami kesulitan belajar yang termasuk dalam klasifikasi perhatian dalam kategorisasi tinggi. 42\% siswa mengalami kesulitan belajar yang termasuk dalam klasifikasi thingking disorder dalam kategorisasi sedang. 36\% siswa mengalami kesulitan belajar yang termasuk dalam klasifikasi memory disorder dan thingking disorder dalam kategorisasi rendah, 43\% siswa mengalami kesulitan belajar yang termasuk dalam klasifikasi dalam menghitung yang termasuk dalam kategorisasi sangat rendah.

Setiap individu tidak ada yang sama, perbedaan individu ini yang menyebabkan perbedaan tingkah laku belajar di kalangan siswa. Dalam keadaan apapun, dimana siswa tidak dapat belajar sebagaimana mestinya, itulah yang disebut dengan kesulitan belajar. Kesulitan belajar pada anak disebabkan oleh kurangnya dukungan dari lingkungan keluarga. Lingkungan keluarga merupakan lingkungan pertama yang dikenal anak dan memberikan pengalaman pendidikan pertama (dalam Koestoro.P dan A. Hadisuparto,1998)

Sementara itu, Siti Mardiyanti dkk. (1994) menganggap kesulitan belajar sebagai suatu kondisi dalam proses belajar yang ditandai oleh adanya hambatan tertentu untuk mencapai hasil 
belajar. Hambatan tersebut mungkin disadari atau tidak disadari oleh yang bersangkutan, mungkin bersifat psikologis, sosiologis, ataupun fisiologis dalam proses belajarnya.

\section{KESIMPULAN DAN SARAN}

\section{Kesimpulan}

Berdasarkan hasil analisis data dan pembahasan dari hasil penelitian, maka dapat disimpulkan bahwa: Tingkat kesulitan belajar siswa kelas VIII di SMP Negeri 50 Batam termasuk dalam kategori sedang. Adapun klasifikasi kesulitan belajar tertinggi yang dialami oleh siswa kelas VIII di SMP Negeri 50 Batam adalah terdapat pada klasifikasi kesulitan belajar memory disorder. Sedangkan klasifikasi kesulitan belajar dalam klasifikasi menghitung.

\section{Saran}

Berdasarkan hasil yang telah diperoleh dari penelitian yang dilakukan di SMPN 50 Batam diharapkan pihak sekolah dapat membantu siswa dalam mengatasi tingkat kesulitan belajar siswa dengan metode yang lebih tepat sehingga belajar mengajarakan lebih efektif dan siswa juga dapat memahami materi yang disampaikan oleh guru.

\section{DAFTAR PUSTAKA}

Abdurrahman, Mulyono. (2003) Pendidikan Bagi Anak Berkesulitan Belajar. Jakarta: Rineka Cipta.

Ahmadi, Abu.\& Supriyono, Widodo. (2013). Psikologi Belajar. Jakarta: PT. Rineka Cipta.

Anggina Pratiwi. (2014). "Identifikasi Faktor-Faktor Penyebab Kesulitan pada Siswa SMP Negeri 5 Kota Jambi”. Skripsi, tidak diterbitkan, Universitas Jambi, Jambi.

Arikunto, Suharsimi. (2006). Prosedur Penelitian Suatu Pendekatan Praktik. Jakarta: Rineka Cipta.

Azwar, Saifuddin. (2003). Reliabilitas dan Validitas. Yogyakarta: Pustaka Pelajar.

A.Muri Yusuf. (2005). Metodologi Penelitian. Padang: UNP Press. 
Depdiknas. (2003). Undang-Undang RI Nomor 20, Tahun 2003, tentang Sistem Pendidikan Nasional.

Erika Ristiyani dan Evi Sapinatul Bahriah. (2016). Analisis Kesulitan Belajar Kimia Siswa Di SMA N X Kota Tangerang Selatan. Jurnal Penelitian Dan Pembelajaran IPA Vol.2 No.1.

Erny Untari. (2013). Diagnosis Kesulitan Belajar Pokok Bahasan Pecahan Pada Siswa KelasV Sekolah Dasar. Jurnal Ilmiah STKIP PGRI Ngawi Vol 13 (01), 1-8.

Fajar Hidayati. (2010). "Kesulitan Belajar Siswa Kelas VII SMP Negeri 16 Yogyakarta dalam Mempelajari Aljabar". Skripsi, tidak diterbitkan, Universitas Negeri Yogyakarta, Yogyakarta.

Hakim, Thursan, (2000). Belajar Secara Efektif, Jakarta: Puspa Swara.

Ilyas, Asmidir. (2011). Meningkatkan Mutu Pendidikan Melalui Kegiatan Diagnosis Kesulitan Belajar. Padang: UNP.

Khoirun Nisa. (2011). “Analisis Kesulitan Belajar Matematika pada Peserta Didik Kelas VIII Semester II Pokok Bahasan Panjang Garis Singgung Persekutuan Dua Lingkaran MTs. Negeri Bonang Tahun Pelajaran 2010/2011”. Skripsi, tidak di terbitkan, Institut Agama Islam Negeri Walisongo, Semarang.

Koestoero,P \& A. Hadisucipto. (1998). Diagnosis dan Pemecahan Kesulitan Belajar. Jakarta: Erlangga.

Siti Sapuroh. (2010). “ Kesulitan Belajar Siswa dalam Memahami Konsep Biologi pada Konsep Monera di MAN Serpong Tangerang”. Skripsi, tidak diterbitkan, Universitas Matana, Tangerang.

Sugiyono, (2013) Metode Penelitian Kuantitati kualitatif dan $R \& D$. Bandung: Alfabeta.

Sukandi, Ujang. (2001). Belajar Aktif dan Terpadu. Jakarta: Brithis Council.

Widya Kartika Sari. (2014). "Hubungan Antara Konsep Diri dengan Kemampuan Komunikasi Interpersonal Remaja di Panti Asuhan dan Implikasinya dalam Bimbingan Konseling". Skripsi, tidak diterbitkan, Universitas Negeri Padang, Padang.

Winarsih. (2013). "Upaya Guru dalam Mengatasi Kesulitan Belajar Membaca, Menulis dan Berhitung pada Siswa Kelas 1 SD Negeri Jatiroto, Wonosari, Purwosari, Girimulyo, Kulon Progo". Skripsi, tidak diterbitkan, Universitas Janabadra, Yogyakarta. 